\title{
Vignettes From a Lifetime of Studying Performance
}

\author{
Richard Schechner
}

\begin{abstract}
In this commentary, summarized from a recent interview, the author shares insights and memories from a career devoted to drama and performance studies. He enthusiastically recounts events, initiatives, and collaborations that have helped sustain his lifelong passion for performance.
\end{abstract}

\section{Prologue: New York City, April 27, 2020}

There is no darkness that doesn't have some light. It's very nice to be in a city where there is 60 to $80 \%$ less air pollution; where the sky is clear; there is very little traffic, you can breathe. When you go out in the morning and take a walk, the streets are pretty empty, but you do this dance if somebody comes near you, you move away.

The negative, of course, is that it's a night without a clear dawn in the sense that when it gets dark tonight at 7:30 or 8:00 pm, I know that at 6:30 or 7:00 am the light will come up. I'm not sure when the light is going to come up with this pandemic.

\section{Developing a Critical Distance}

As I got into my late teenage years and decided to go college, I saw myself at that point as a writer and literary person. My undergraduate degree was in English and Philosophy with a lot of Psychology. I started to do lots of writing during that period. I was at Cornell University at the daily newspaper, The Cornell Daily Sun, and I wrote for it intensively. When I was a senior, I probably could have stood to be editor-in-chief, but by that time I was more reflective, so I decided to become the editorial page editor, who oversees the opinions of the paper, and also I was a drama reviewer. This latter role allowed me to see lots of school plays—some I liked and some I didn't like—but I developed a critical distance.

\section{Environmental Theatre}

Later on, I became a director of East End Players in Provincetown, Massachusetts, a summer theatre where we did extraordinary plays: Sartre's No Exit, Ionesco's The Lesson, Ibsen's Master Builder, Sophocles' Philoctetes, and more. It wasn't your normal summer theatre. I ran it for two years and we did some productions in what I later called "environmental theatre." For example, Philoctetes we did on the beach, and the boat with Neoptolemus and Odysseus arrives on the beach-and the audience is on the beach — and Philoctetes stumbles up and he's got his bloody rags and the flies are there because we used real fish blood, and they try to talk him into going back to finish the Trojan War. 


\section{Blessing of the Fleet}

I did a master's degree in English, but I started to move over into drama, into theatre. I went to Johns Hopkins University for a year and then transferred to the University of lowa. I was in Paul Engle's lowa Writers' Workshop, which was a very fancy place and hard to get into. I thought of myself as a playwright and fiction writer and continued to write poetry, which I still do today. I was working in the Theatre Department at the same time and my thesis was a play called Blessing of the Fleet, which was about the fishermen of New Bedford, Massachusetts.

At any rate, I was writing plays and they were getting produced, and at the same time I was running this theatre. Then in November 1958 I volunteered for the draft, I went into the army. I could have avoided the draft; I was more than 24 years old. I already had a master's degree and I probably could've got a commission. But I did not want to be an officer. I wanted to be with people who were not of my class or background. I'm more or less middle- to upper-middle-class. Being a private in the army put me in touch with totally different kinds of people from those I grew up with, went to college with. I also directed a play in the army and very theatrical things happened there. But those are stories to tell another time.

\section{Shifting My Focus}

When I came out of the army in August 1960, I moved to New Orleans for reasons that were both personal and professional. I went to Tulane University and got my PhD in 1962. Right as I was finishing my PhD, they offered me a job to become editor of TDR — the Tulane Drama Review at that point-The Drama Review now. There were 17 years when I wasn't editor, from 1969 to 1986, but I think if you add it up it's the longest editorship of a scholarly journal ever, about 40 years total out of a span of 67 years. Being editor of $T D R$ and a professor of theatre shifted my focus from writing plays, poetry, and fiction to scholarly criticism and performance theory. I didn't stop doing creative writing, but I did a lot of the other kind of writing too. I put my creative energy into directing.

As a director I often rewrote, collaged, or adapted the texts I was doing. Sometimes people attacked me for this. When I did Dionysus in 69, based on Euripides The Bacchae, I worked with the company I founded in New York-The Performance Group - to make a new textual collage combining Euripides in translation with the performer's own experiences, improvised music, and audience participation. When I did Makbeth with a "k," I restructured Shakespeare's Macbeth and so on. Even as a director I was a writer. This kind of thinking influenced my teaching. As a professor, I wanted to apply the insights I was having into what constituted theatre. I had become very interested in ritual and wanted to apply that to my teaching and my directing. I wanted to be a "whole person" in the classroom as well as put "whole persons" on the stage. My works on the stage were radical and environmental. They involved audience participation, they were social, they had rituals in them, and they deconstructed and recombined texts. All these things which are so common now were not common in the 1960s and 1970s. Even before I moved to New York, I was doing this kind of experimenting. Nor was it common then to do "practice as research" in the classroom, to teach viscerally as well as intellectually. 


\section{Text as a Prompt for Performance}

At Tulane, I was an Assistant and then Associate Professor of Drama. I was already teaching drama in the context of what happens when you embody the drama, and not simply read the text. And I always thought of the text as a prompt for a performance, and a performance as an illumination and version of the text. I never felt that the playwright's words were sacrosanct. I felt that once the play entered into the process of rehearsal with the performers, you could play with it. Now certain texts, obviously, you're not going to play with. If you're doing Shakespeare, you should do Shakespeare. But even there, maybe not. Is West Side Story Shakespeare? Was The Performance Group's Makbeth? A couple of years ago I devised with East Coast Artists-another group I founded_Imagining $O$ which conflated and combined Hamlet with a French erotic novel, The Story of $O$, and the experiences of the performers I was working with. At present, I am working on Dark Yes, which deconstructs-reconstructs Joseph Conrad's Heart of Darkness and James Joyce's Ulysses (Molly Bloom's soliloquy). In China, I directed Hamlet without changing the text, a Mandarin translation of the play.

\section{A Different Type of Drama Department}

When I moved to New York to NYU in 1967, I was brought there by Robert W. Corrigan, the founding editor of TDR and my dissertation director at Tulane. When Corrigan left Tulane for Carnegie Tech (now Carnegie Mellon University), I replaced him at Tulane. Then he went to NYU and became the first dean of the School of the Arts, which is now the Tisch School of the Arts. He asked me to be the head of Graduate Drama Department at NYU. I didn't want to be the head. I'm not the kind of person who likes to be a departmental chair. Except for one year, I've avoided that. I suggested, and Corrigan agreed, to bring Monroe Lippman who headed the Theatre Department at Tulane to chair the Graduate Drama Department at NYU. Then over the next 10 years or so, I was one of the driving forces transforming this department into what finally in 1980 was renamed the Performance Studies Department.

\section{Approaches to Theory and Criticism}

We accomplished that by first bringing in Brooks McNamara, who like me had his PhD from Tulane. Brook's specialty was theatre history from the perspective of popular entertainments - from P.T. Barnum to music halls and Broadway. Then we hired Michael Kirby, a visual artist and performance artist who wrote one book about Happenings and another about what he called "the new theatre," which included the kind of dance being practiced at Judson Church, postmodern dance. Kirby was a friend of Allan Kaprow and he introduced me also to John Cage and that whole world of performance art-though it wasn't called that then. A little earlier I read Erving Goffman's Presentation of Self in Everyday Life. The chapter on performance was extremely important to me because Goffman defined performance as any situation when people interact in ways that are to some degree prepared or rehearsed, even if only mentally. Goffman situated performance within a social, rather than, an aesthetic, realm. Goffman's work, along with my study of the Cambridge Anthropologists' theories of the ritual origins of Greek tragedy, led me to publish in TDR in1966, the year before I came to NYU, "Approaches to Theory and Criticism." In that essay I theorize the broad spectrum of performance: play, sports, the performing arts, 
popular entertainments, and ritual. I rejected the Cambridge thesis arguing instead that ancient Greek theatre emerged from the tension and confluence of play and ritual. I thought that "performance" was itself originary. "Approaches" set out the basic framework of what was to become performance studies. In the early to mid 1970s, I wrote a series of essays expanding on what I first explored in "Approaches." These key essays were collected in 1976 in my book, Essays on Performance Theory, which has been revised and reissued several times with the title Performance Theory. This book, and my 1985 Between Theater and Anthropology, contain the basic theories that have guided much of my scholarly work.

\section{Collaboration With Victor Turner}

Another decisive input came from my first reading and then meeting and working very closely with anthropologist Victor Turner. In 1969 Turner published The Ritual Process and in the early 70s, Dramas, Fields and Metaphors. These key works detail Turner's theories of liminality, communitas, and social drama. Turner and I met in 1976 when he invited me to participate in a conference he was organizing on ritual, play, and performance. Turner and I hit it off from the start. Our first meeting was supposed to be a half-hour beer, but it turned out to be hours of intense conversation about shared ideas. Being kindred spirits, we began a very deep collaboration that culminated in a series of conferences. That work is summarized in the book By Means of Performance, which I edited with Willa Appel. Turner and I continued to work together until his death in 1983. He visited NYU a number of times. Through him I met his wife, anthropologist Edith Turner, and many other deep scholars of performance such as Barbara Myerhoff, Paul Bouissac, Bruce Kapferer, Roberto DaMatta, and John MacAloon.

\section{Between Theater and Anthropology}

In the early-to-mid 1970s, I began a series of courses at NYU called "Performance Theory." I was following through on my work with Turner and his crowd. But also I was building on my work with the great Polish experimental theatre director, Jerzy Grotowski. Grotowski put into practice environmental theatre, performance theory, ritual, and rigorous performer training. Later in his career, Grotowski investigated "paratheatre," performance outside of the aesthetic realm. My performance theory courses were deeply tied into the investigations of Turner and Grotowski. Others too, of course, as I have indicated. But the work of these two geniuses was of inestimable importance to me. The format of the performance theory courses was that each term we would focus on a different basic subject, like "shamanism" or "ritual" or "play." It was never theatre, dance, or drama as such but performanceincluding the aesthetic genres — was always important. The course was "between": between theatre and anthropology, between art and ritual and play, between social life and artistic practice, between politics and performance. David Oppenheim, who was dean of the NYU School of the Arts at that time, encouraged me by giving me a budget for the course which allowed me to invite a different key figure each week. The guest would deliver a public lecture on Monday night and then meet with my graduate seminar class on Tuesday morning. That course morphed into the core of performance studies. 


\section{Don't Reject Doing Something Because You Can't Master It}

Let me return to Grotowski. In 1967, I was among those who invited Grotowski to come to NYU and do a workshop. Because of my work on TDR, I had known Grotowski since 1963, although we met face-to-face only in 1966. When Grotowski came to NYU for the workshop, I insisted that I participate fully, even though I was a professor at that time and all the others in the workshop were graduate students. But I knew that to participate in something in an embodied way is how you can understand it most deeply. It is not so important that I master a technique, though that is a good idea if you have the time and ability. What is decisive is to "get" what is being taught viscerally. I say to people, "don't reject doing something because you can't master it, because even in failing to master a skill you will still learn a great deal about." In other words, if a great chef says they want to teach you how to cook, don't think that because you will never become a great chef you shouldn't try to cook or learn as much as you can, even profiting from mistakes. Grotowski's ideas on audience participation in structuring the space was very much in harmony with what I was doing. He felt that theatre performance was more than entertainmentit also had a ritual component and a deep learning performance. All this was very important to the formation of performance studies. And in the development of my theatre, The Performance Group.

\section{Educere-To Lead Out Of}

Let me go back to when I was a teenager. Perhaps the course that meant the most to me in high school was Latin. I studied it for four years. I never became proficient. But I learned a great deal-about language, Roman culture (and the Greek culture that stood before Rome), and about how to learn. Not as religion so much as about discourse, living, and the dialogic-Socratic method of learning. I didn't like much of high school and I was a bad student to some degree, disciplinarily speaking. The other subjects never occupied my attention, but Latin did. The other great learning experience from my boyhood were the things my mother's father, Samuel Schwarz, taught me from The Bible and The Talmud. Education is a Latin-based word. It literally means to "lead out of" or Educere. What are you leading a person out of? At one level, of course, it's chronological: you're leading a person out of their childhood into adolescence or out of adolescence into early adulthood, and so on, throughout life if you are wise enough to keep educating yourself. At a philosophical level, education is not chronological. It's being led out of ignorance into knowledge, out of darkness into light. However, these matters are very paradoxical: the greatest thing you can teach a student is that they'll always be ignorant and therefore they're always in the process of learning and finding the light insofar as the light can be known. Finding the "truth" insofar as it can be known. I am a profound philosophical relativist. I think truth is socially constructed and that it is always contested and always temporary. That is also the scientific method. Science is a system of practice-thought where new knowledge replaces old, where all hypotheses are provisional; where even "proof" is not necessarily so for all times in all circumstances. Who would have thought that light bends? 


\section{Performance Is Never Quite a Finished Product}

You've been successful as a teacher if the student comes out feeling comfortable about asking questions. And that's also what performance is, because performance to me is fundamentally rehearsing: a "finished performance" is rehearsals stopped at a certain point. A finished production is simply the time when you say: "Okay, I'm stopping the rehearsals; I'm going to open it at this point." It's not exactly like baking bread, which is very interesting. Because if you bake bread you have a recipe, prepare the bread batter, put it in the oven, take it out, and eventually eat it. However, I think performance is a bread that's constantly being yeastified. You keep adding to it, it's constantly rising, but it's never quite finished.

\section{What Matters Is Achieving Harmony}

I've also learned to listen. I like to listen and play with my students. Some part of the class will always be on our feet, moving, or singing. I might surprise a student or a class one day when they come in and I ask them to sing their reaction to a text: "How does it sound if you have to put a tune to it?" And they say: "What do you mean?" And I say: "I don't really know what I mean. What do you think I mean? Give it a try." And the worst that can happen is that their singing is terrible! Or dance a problem. I tell my students: "We're here for a few hours, so what's so terrible about 10 minutes of failure, what does it matter?" What matters is that you get that stuff between your ears and that stuff in your belly in harmony with each other. Or at least in conversation with each other.

\section{Epilogue: Some Final Thoughts on the Pandemic}

I do think we will come through this and hopefully we'll come to a more humane and better world because we'll realize our vulnerabilities and realize that we have to share, think, and act constructively for the future. I think that art, performance, and education have large roles to play because what goes on in the imagination is a prelude to what can go in concrete physical fact.

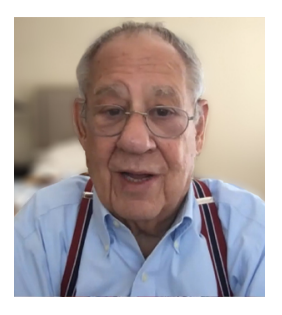

Richard Schechner is University Professor Emeritus, Tisch School of the Arts, NYU. He is the editor of TDR: The Journal of Performance Studies. He is the founder of The Performance Group and East Coast Artists and has directed plays and/or conducted performance workshops in North and South America, Europe, Africa, Asia, and Australia. He is the general editor of the Enactments Book Series for Seagull Books, Kolkata, distributed by the University of Chicago Press and the Worlds of Performance Book Series for Routledge. His books include Environmental Theater, The End of Humanism, Performance Theory, Between Theatre and Anthropology, The Future of Ritual, Performed Imaginaries, and Performance Studies-An Introduction (4th edition, 2020). His writings have been translated into more than 20 languages. He has been awarded Guggenheim, NEH, Asian Cultural Council, Leverhulme, and Erasmus Mundus fellowships. He has fellowships from or been a visiting professor at 17 universities in the United States, Europe, and Asia including Dartmouth, Cornell, Princeton, the Shanghai Theatre Academy, the Institute for Applied Theatre Studies (Giessen), and Goethe University (Frankfurt). He is the recipient of several "lifetime achievement" awards and three honorary doctorates. 